Anais da Academia Brasileira de Ciências (2013) 85(4): 1215-1216

(Annals of the Brazilian Academy of Sciences)

Printed version ISSN 0001-3765 / Online version ISSN 1678-2690

http://dx.doi.org/10.1590/0001-37652013854

www.scielo.br/aabc

\title{
EDITORIAL NOTE
}

\author{
Heavy metals partitioning in the Rodrigo de Freitas lagoon; \\ larvicidal potential of a new essential oil against Aedes aegypti; and \\ the socioeconomic impact of tourism due to wild dolphins provisioning
}

\author{
ALEXANDER W.A. KELLNER \\ Laboratório de Sistemática e Tafonomia de Vertebrados Fósseis, Departamento de Geologia e Paleontologia, \\ Museu Nacional/UFRJ, Quinta da Boa Vista, s/n, Bairro Imperial de São Cristóvão, 20940-040 Rio de Janeiro, RJ, Brasil
}

Pollution is one of the main concerns for humanity, having a variety of causes (e.g., Ferraz et al. 2005, Lacerda et al. 2012). Hardly disputable, urbanization can be regarded as the leading factor in introducing pollutants to the environment, and due to the actual population growth, will continue to be so in the foreseeable future. Despite the mounting general willingness of governments and policymakers to establish programs that can mitigate some of the negative side effects of urbanization, in many cases there is still a lack of knowledge regarding the processes that enable pollutants to spread and increasingly develop a negative role in the long term, such as the contamination of water by heavy metals.

In the last publication of the year of the Anais da Academia Brasileira de Ciências (AABC), Estefan M. da Fonseca (LAGEMAR - Universidade Federal Fluminense, RJ) and colleagues address the issue on how heavy metals are being fractioned in a specific polluted area situated directly in the heart of the city of Rio de Janeiro: the Rodrigo de Freitas lagoon. That the pollution in this mix of salt and fresh water body is a constant concern to authorities is not a novelty, but several details particularly regarding the distribution and dissemination of heavy metals are still unknown. Fonseca et al. (2013) collected core samples in four distinct points of the Rodrigo de Freitas lagoon and analyzed the degree in how the sediments, particularly the humic compounds, affect the fractioning of heavy metals. This is a start in trying to understand the potential impacts including the potential export of heavy metals to areas nearby this lagoon, and how this might affect the biota, as has been documented in other areas (e.g., Wang et al. 2004, Oliveira et al. 2011).

Another article published in this issue of the AABC concerns dengue. This tropical disease is becoming increasingly lethal in Brazil. As known, the main vector of dengue is Aedes aegypti whose distribution is not limited to the country but widely found in the Americas (Costa et al. 2005). Several attempts to develop substances with larvicidal effects against this mosquito have been published, including studies on essential oils obtained from Piper (e.g., Leyva et al. 2009), a flowering plant that belongs to the so-called pepper family. Gisele L. Oliveira (Universidade Federal do Rio de Janeiro, RJ) and colleagues have determined the major constituents of the essential oil obtained from the species Piper aduncum and examined its potential larvicidal activity against Aedes aegypti. The oil was extracted from leaves collected from northern 
Minas Gerais, from the typical Brazilian Cerrado. This plant is commonly employed by local inhabitants for the treatment of a variety of diseases ranging from respiratory problems to gynecological disorders (e.g., Coimbra 1994). Oliveira et al. (2013) were able to establish the effectiveness of the essential oil obtained from this plant in different concentration that might be a start for the development of a natural product against Aedes aegypti and which would help in the control of dengue.

A last contribution that I would like to highlight from the present issue of the AABC, is the study by Luiz C.P.S. Alves (Universidade do Estado do Rio de Janeiro, RJ) and colleagues that deals with what is increasingly becoming an interesting tourist attraction: swimming with wild dolphins. Although studies to understand how natural resources are being used by local communities are not uncommon (e.g., Rocha et al. 2012), in this case the authors try to determine how local inhabitants of the Central Amazon region feel about the socioeconomic advantages of developing a tourist activity which has great negative impact on the wild life (Alves et al. 2013), as has been shown with regards to dolphins before (e.g., Orams 2002). This result is somewhat surprising and might help policymakers rethink the use of the natural resources in some national parks.

\section{REFERENCES}

Alves lCPS, Zappes CA, Oliveira RG, Andriolo A And Azevedo A de F. 2013. Perception of local inhabitants regarding the socioeconomic impact of tourism focused on provisioning wild dolphins in Novo Airão, Central Amazon, Brazil. An Acad Bras Cienc 85: 1577-1591.

COIMBRA R. 1994. Manual de fitoterapia. $2^{\mathrm{a}}$ ed., Belém: CEJUP, 196 p.

Costa JGM, Rodrigues FFG, Angélico EC, Silva MR, Mota ML, SANTo NKA, CARdoso ALH And Lemos TLG. 2005. Estudo químico-biológico dos óleos essenciais de Hyptis martiusii, Lippia sidoides e Syzigium aromaticum frente às larvas do Aedes aegypti. Rev Bras Farmacogn 15: 304-309.

FERrAZ SFB, VetTorazZi A, THEOBALD DM AND BALLESTER MVR. 2005. Landscape dynamics of Amazon deforestation between 1984 and 2002 in central Rondônia, Brazil: assessment and future scenarios. Forest Ecol Manag 204: 67-83.

Fonseca EM da, Baptista Neto JA, McAlister J, Smith B, Fernandez MA And Balieiro FC. 2013. The role of the humic substances in the fractioning of heavy metals in Rodrigo de Freitas Lagoon, Rio de Janeiro - Brazil. An Acad Bras Cienc 85: $1289-1301$.

Lacerda LD, Bastos WR And Almeida MD. 2012. The impacts of land use changes in the mercury flux in the Madeira River, Western Amazon. An Acad Bras Cienc 84: 69-78.

Leyva M, Marquetti MDC, TACoronte JE, Scull R, Tiomno O, Mesa A And Montada D. 2009. Actividad larvicida de aceites esenciales de plantas contra Aedes aegypti (L.) (Diptera: Culicidae). Rev Biomed 20: 5-13.

Oliveira GL, CARdoso SK, LARA Júnior CR, VieIra TM, Guimarães EF, Figueiredo LS, Martins ER, Moreira DL AND KAPLAN MAC. 2013. Chemical study and larvicidal activity against Aedes aegypti of essential oil of Piper aduncum L. (Piperaceae). An Acad Bras Cienc 85: 1227-1234.

Oliveira SMB de, Pessenda LCR, Gouveia SEM AND FaVAro DIT. 2011. Heavy metal concentrations in soils from a remote oceanic island, Fernando de Noronha, Brazil. An Acad Bras Cienc 83: 1193-1206.

ORAMS MB. 2002. Feeding wildlife as a tourism attraction: Issues and impacts: Tourism Manage 23(3): 281-293.

Rocha MSP, SANTIAGo IMFL, CORTEZ CS, TRINDADE PM AND MOURÃo JS. 2012. Use of fishing resources by women in the Mamanguape River Estuary, Paraíba state, Brazil. An Acad Bras Cienc 84: 1189-1199.

WANG H, WANG CX, WANG ZJ AND CAO ZH. 2004. Fractionation of heavy metals in surface sediments of Taihu Lake, East China. Environ Geochem Health 26: 303-309. 